\title{
Indian University Libraries
}

There is a venerable history of academic libraries in India, dating at least from the sixth century. Today's libraries, however, despite their long history and the substantial body of new theorizing concerning them, are hampered by the absence of book-oriented teaching, adequate budgets, or proper administrative organization and support. An intelligent, informed, and aggressive library profession is probably the nation's most valuable library asset today.

$\mathrm{T}_{\mathrm{H}}$ HE PURPOSE of this paper is to present some thoughts, observations, and discussion on the history and the problems of academic libraries in India.

In systematic library technique and methodology, the Indian university library is a product of the twentieth century. The modern concept of the university library and of libraries in general has been elucidated through the writings and speeches of the Indian library genius $-\mathrm{S}$. R. Ranganathan. It would be incorrect to assume, however, that ancient college and university library collections were non-existent, for India has a long literary heritage.

\section{EARLy History}

The University of Taxila in northern India was a flourishing center for learning as early as the sixth century B.C. Students came to Taxila for specialization in the Vedas, Hindu grammar, and philosophy. The university possessed a large collection of manuscripts on these subjects. During the invasions of the fifteenth century the school was ruined and the city destroyed, thus extinguishing the glow from this early center of learning.

Mr. Toney is Assistant Professor, Department of Library Science, Central Michigan University, Mr. Pleasant, Michigan.
The seventh-century Chinese traveler and scholar, I-Tsing, studied for ten years at the University of Nalanda where many Chinese, Japanese, and Korean scholars came to learn. The university possessed a well-equipped, subject-classified library collection housed in three buildings, one of which was nine stories high. Nalanda flourished from the fifth to the late twelfth centuries.

The Buddhist monastery and university at Vikramaila, founded by King Dharampala in the eighth century A.D., had a distinguished collection especially rich in the Hindu religion. This school was patronized by the Indian rulers until the thirteenth century, and at its zenith it had eight thousand monk-scholars using its collection.

From the eleventh through the thirteenth centuries a large number of temple-colleges existed in India. One temple college, Chatikasal in southern India, had a faculty of three Vedic teachers, three Sastras teachers, and a staff of six librarians whose status was about equal to that of the professor of the time. ${ }^{1}$

Even though it is estimated that during the Muslim conquests (thirteenth to sixteenth centuries) several hundred

\footnotetext{
${ }^{1}$ For more information on ancient schools and libraries refer to Shri G. L. Trehan, "Libraries in Ancient and Medieval India," Development of Libraries in New India, ed. N. B. Sen (New Delhi: New Book Society of India, 1965), p. 98-103.
} 
thousand manuscripts were lost, some of the conquerors who had destroyed libraries subsequently began to rebuild them. Many important manuscript collections were established during the Moghul times. One of the most important was that of Akbar the Great (15961605). Another Moghul ruler and bibliophile was Humayun (1530-1540) whose librarian, Lal Beg, built the imperial library collection at Agra. It was said of Humayun that one evening emerging from his library in an especially thoughtful mood he stumbled and fell to his death.

\section{Historical INFLUENCES AND Present Problems}

Despite evidences of early notable collections, there gradually developed in India a disinterest in libraries that in more recent times produced a condition of terrible neglect.

Though the Jesuits introduced into India (1556) the art of printing by movable type, neither the Moghul rulers nor the independent Maratha chiefs were interested in the printed book. One historian writes that-

a primary deficiency in the culture of the Marathas was their ignorance of the art of printing and their failure to make an effort to learn it. During the period between May 11,1498 , the date on which da Gama discovered India, and 1760, the Portuguese and the Marathas established contacts on many occasions. . . . The fact that in spite of [these contacts] they did not pick up the art of printing detracts greatly from the reputation of the Marathas for their ability to imbibe new ideas. ${ }^{2}$

It must be admitted that while insensitivity to intellectual advance was shown by both Moghul and Maratha rulers, the Portuguese and the Catholic missionaries did little on their part to encourage interest of the Indian people in anything

2A. K. Ohdedar, The Growth of the Library in Modern India: 1498-1836 (Calcutta: World Press, Ltd., 1966), p. 9-10. but religion or related topics. An Englishman in 1832 described the contents of the ten thousand volume library of the Augustinian monks at Goa as containing

... a few bad editions of classics, but not a complete edition, even of Cicero himself; a great many schoolmen, casuists, and economists, with some jurists; very little history, scarcely any of modern times, except a little Portuguese; about ten volumes of Portuguese and Spanish poetry ... no politics, [no] political economy, no mechanics, no hydrostatics, no optics, no astronomy, no chemistry, no zoology, no botany, no mineralogy and no book ... on mathematics $\ldots 3^{3}$

From the beginning of British influence in India, with the formation of the East India Company in 1601, and up to the mid-eighteenth century, there was slight interest in building college and university libraries. Furthermore, the English gentlemen of that era in India cared little himself for literary or scholarly pursuits. As one journalist commented "It may appear as though the daily life of the Englishman in Bengal was devoid of the civilizing influences of literature. And it has been said that commercial pursuits were not very consistent with literary tastes in Old Calcutta; the jingling of rhymes was discord to the rattling of rupees . ..."4

Not only was no impetus given to the growth of library collections during much of the British period, but the system itself discouraged the development of worthy collections. The average Indian student in his higher education made little or no use of libraries. He mainly studied lecture notes in order to pass all-important examinations that would qualify him for service in the British India offices. An 1882 report evaluating education found "the general reading of students is confined to the books which have some bearing on the subject of ex-

Ibid., p. 10-11.

4 Ibid., p. 44. 
amination." 5 This lack of incentive to independent study, in part a legacy of the British administrative system, even today characterizes campus life. Thus many Indian librarians feel today that the university library is frequented much less by the average undergraduate student than it should be. ${ }^{6}$ The inordinate emphasis upon memorizing lecture notes is shown by a recent study revealing that the average Delhi University student was using about eight books during the academic year. ${ }^{7}$

Reference to committee and commission reports published over several decades reveals Indian university libraries have long had budgetary problems. ${ }^{8}$ Now that India is a generation into independence the serious problem of financing university libraries persistslibraries which face ever larger enrollments. In the twenty-year period 1946 to 1965 the University of Delhi student body increased 840 per cent, while the library book collection increased 462 per cent. ${ }^{9}$ This same university with 29,550 students in 1964-1965 had a book collection of 233,998 and a budget of 402,658 rupees $(\$ 53,689) . .^{10}$ Benares Hindu University spent 300,000 rupees $(\$ 40,000)$ in 1962 for books and periodicals. ${ }^{11}$ The Uni-

sp. C. Bose, "School and College Libraries in the Evolution of Education in Modern India," Indian Library Association Bulletin, I (April-June 1965), 16.

- An average Indian university student devotes less than one hour a day to study beyond classroom attendance, while the United States student spends from twenty to thirty hours a week on work outside the classroom. Shri Anand P. Srivastava, "On University Librarianship in India," Development of Libraries in New India, op. cit., p. 239. I was told by the Head Librarian, University of Bombay, that only about 10 per cent of the undergraduate students use the library (interview with Shri D. N. Marshall, Dec. 16, 1966).

${ }^{7}$ Carl White, A Survey of the University of Delhi Library (New Delhi: University of Delhi), p. 10-11. It may be recalled that Branscomb's report of 1940 found the average American undergraduate used from 61.7 to 74.6 books a year.

${ }^{8}$ Several reports acknowledge the seriousness of budget deficiencies; for example: Report of the University Commission, 1902; Calcutta University Commission Report, 1919; Report of the Hartog Committee of 1929; Wood and Abbott Committee Report 1937; and Universities Commission, 1948-49.

White, op. cit., p. 5-6.

${ }^{10}$ Ibid.

${ }^{11}$ Directory of Special and Research Libraries in India (Calcutta: Indian Association of Special Libraries and Information Centres, 1962), p. 25. versity of Bombay with a total enrollment in 1964-1965 of 54,726 had a budget for books and periodicals of 117,427 rupees $(\$ 15,656)$.12 $^{12}$ The University of Mysore library in 1965-1966 spent 50,897 rupees $(\$ 6,786)$ on its collection. ${ }^{13}$ It should be added that many universities rely heavily on supplementary gifts and grants-often from abroad-to augment their collections. Of the 3,513 books acquired by the University of Mysore library in 1965$1966,15.8$ per cent were gifts, while in 1964-1965 the University of Bombay received 45 per cent of its acquisitions in the form of gifts. ${ }^{14}$

There is real need for university libraries to develop stronger specialized collections, especially on graduate and research levels. White, in his report on the University of Delhi (1965), concludes that evidence is "overwhelming" that book collections there are substandard and do not meet the educational needs of the university. When teachers of the university were asked whether the collections were strong enough to support their own research and that of their students on a graduate level, over 90 per cent answering the questionnaire thought they were not. ${ }^{15}$

While some libraries are adequate in certain subject areas, most collections seem thin and superficial, the partial result of imprecisely conceived selection policies. This negative condition might be mitigated by the more extensive utilization of specialized collections on an exchange basis, as has been attempted in the United States. Better communication and cooperation between libraries would further enable institutions to develop in more depth certain areas of local or special interest.

Basic to a properly functioning and growing university library is the neces-

${ }^{12}$ Annual Report for the Year 1964-65 (Bombay: University of Bombay, 1965), p. 54.

${ }^{13}$ Annual Report for the Year 1965-66 (Mysore: University of Mysore, 1966), p. 8-9.

${ }^{14}$ Ibid., p. 8-9; University of Bombay, op. cit., p. 54.

${ }^{15}$ White, op. cit., p. 39. 
sity to define clearly the powers and the legal position of a library in relation to the governing authority of the university. An example of the occasionally ambiguous position of university libraries in India is Delhi. The University of Delhi "library is not recognized as one of the authorities of the University. Omission from the statutes of any definition of its scope and nature leaves a sort of noman's-land of uncertainty and lack of order." ${ }^{16}$ This produces confusing decentralization in the control of library affairs. Even in the relatively routine matter of book selection it is not always clear at Delhi whether items are the property of the library or of the department requesting them. ${ }^{17}$

Such, then, is the picture of the average Indian university library: inadequately financed; frequently unbalanced collections; housed except for a few cases under crowded conditions with antiquated facilities; ${ }^{18}$ often isolated and unable to tap other collections; and generally understaffed. It is a picture that does not at first glance offer great hope for the future.

\section{Tentative Approaches}

One approach to these problems lies with the student himself. Ideally, the Indian student must become aware of what libraries and library services can add to his educational career. Such an awareness by students would certainly generate pressure and impetus toward strengthening university libraries. At present, unfortunately, a self-perpetuating cycle exists whereby the administrator can point to the slight use of libraries in justifying small budgets that in turn hold both collections and services at an undesirable level.

More studies on the reading habits of

${ }^{16}$ Ibid., p. 61.

${ }^{17}$ Ibid.

${ }^{18}$ One exception is the modern library facility at the University of Mysore. students would be useful in enabling the librarian better to anticipate and meet the desires and needs of the students. But thus far investigation of the reading habits and requirements of Indian students has not been great. Whereas such studies seem to some observers almost too plentiful in the United States and Britain, ${ }^{19}$ in India they are a rarity.

Helpful also would be greater effort to strengthen channels between the departments of the university and the library. The use of available funds would be enhanced by a closer relationship between instructional needs and library resources. Too often instructors do not really know what is in the library, with the result that students are expected to become familiar with materials that are unavailable. ${ }^{20}$ There are also occasions when existing library resources are insufficiently utilized by instructors. The responsibility for this condition rests not entirely with the library, though as a central agency it is logical that the library should take initiative in remedying any lack of fruitful communication.

It is easy to conclude that more money for library collections and facilities would furnish the entire solution to existing problems. To a large degree lack of funds is the source of most inadequacies, yet librarians familiar with the situation in India recognize that the demand elsewhere in society for available money is so great that it will doubtless be some time before library budgets can or will receive a high priority. ${ }^{21}$ Short of larger

\footnotetext{
19 Srivastava says that between 1881 and 1957 there were about 3,600 such studies in the United States and Great Britain. Op. cit., p. 240.

${ }^{20} \mathrm{~A}$ course syllabus at the University of Delhi listed the literary works of fifty-two authors, with but 37 per cent of these volumes in the library. White, op. cit., p. 41 .

21 There has been some increase in budgets over the years. Of the total budget for university education in the First Five Year Plan the purchase and binding of books and periodicals accounted for 1.7 per cent of the budget. In the Second Plan it accounted for 2.8 per cent; and in the Third Plan, for about 5 per cent. R. Kalia, "Libraries in the Fourth Five Year Plan," Indian Library Association Bulletin, I (JanuaryMarch 1965), 8.
} 
budgets, the sensible approach seems to be more concentration on fuller and better utilization of existing collections; promotion of greater student use of libraries; and closer administration-facultylibrary relations. Even the most worthy collections and adequate budgets are of little value unless there is realization of the important role libraries can and should play in the life of a modern university.

Fortunately the library profession in In- dia is intelligent, imaginative, and of high attainment. It is probably the greatest single asset of the Indian library movement at present, since while working under trying conditions it is nonetheless building better libraries for the country. The men and women within it realize the importance of their role in contributing to the development of a new dynamic India, while preserving for future generations the heritage of this ancient land.

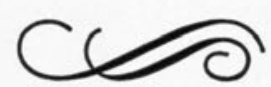

